\title{
Okul öncesi öğretmenlerinin rehberlik yeterlilikleri ile sınıf yönetimi becerileri arasındaki ilişkinin incelenmesi
}

\author{
An examination of the relationship between the counselling \\ qualifications and the classroom management skills of pre-school \\ teachers
}

\author{
Hülya Bilgin ${ }^{1}$
}

\begin{abstract}
Makale Geçmişi
Geliş : :02 Ağustos 2019

Düzeltme : 29 Ağustos 2019

Kabul : 11 Eylül 2019

Çevrimiçi : 13 Eylül 2019
\end{abstract}

\section{Makale Türü}

Araştırma Makalesi
Article History

Received : 02 August 2019

Revised : 29 August 2019

Accepted : 11 September 2019

Online : 13 September 2019

\section{Article Type}

Research Article

\begin{abstract}
Öz: Bu araştırmanın amacı okul öncesi öğretmenlerinin rehberlik yeterlilikleri ile sınıf yönetimi becerileri arasındaki ilişkiyi incelemektir. Araştırma ilişkisel tarama modelinde tasarlanmıştır. Araştırma, 2018 eğitim öğretim yllı İstanbul ilinde görev yapan 159 kadın, 11 erkek toplam 170 okul öncesi öğretmeni ile gerçekleștirilmiștir. Araștırmada kullanılan ölçme araçları, Okul Öncesi Öğretmeni Rehberlik Yeterlilikleri Ölçeği ve Okul Öncesi Öğretmeni Sınıf Yönetimi Ölçeği’dir. Verilerin analizinde Pearson Momentler Çarpımı Korelasyon Katsayısı ve Basit Doğrusal Regresyon kullanılmıştır. Elde edilen sonuçlara göre, okul öncesi öğretmenlerinin rehberlik yeterlilikleri ile sınıf yönetimi becerileri arasında anlamlı bir ilişki bulunmaktadır. Aynı zamanda her iki ölçeğin alt boyutları açısından da anlamlı bir ilişki vardır. Yapılan basit doğrusal regresyon analizi sonucunda okul öncesi öğretmenlerinin rehberlik yeterliliklerinin okul öncesi öğretmenlerinin sınıf yönetimi becerilerindeki değişimin yaklaşı \% \%38'ini açıkladığı görüşmüştür. Aynı zamanda okul öncesi öğretmenlerin rehberlik yeterliliklerinin okul öncesi ögretmenlerinin sınıf yönetimi becerileri üzerinde anlamlı bir yordayıcı olduğu tespit edilmiştir.
\end{abstract}

Anahtar Kelimeler: Okul öncesi öğretmeni; Rehberlik yeterlilikleri; Sınıf yönetimi
Abstract: The purpose of this research is to examine the relationship between the counselling qualifications and the classroom management skills of pre-school teachers. The relational screening model has been used in the design of the research. The research has been conducted with 170 preschool teachers serving in Istanbul in the 2018 academic year, of whom 159 are women and 11 are men. Measurement tools used in the research are the Scale for the Counselling Qualifications of Pre-School Teachers and the Scale for the Classroom Management of Pre-School Teachers. The Pearson productmoment correlation coefficient and the Simple Linear Regression have been used in the analysis of the data. According to the obtained results, it was observed that a meaningful relationship exists between the counselling qualifications and the classroom management skills of pre-school teachers. In addition, a meaningful relationship also exists with respect to the sub dimensions of both scales. As a result of the simple linear regression analysis, it was seen that the counselling qualifications of the pre-school teachers accounted for $38 \%$ of the change in the classroom management skills of the pre-school teachers. In addition, it was determined that the counselling qualifications of pre-school teachers constituted a meaningful precursor to their classroom management skills.

Keywords: Pre-School teacher; Counselling qualifications; Classroom management 


\section{SUMMARY}

\section{Introduction}

Pre-school teachers spend almost all of their time with their students during school hours, support them in every environment, and try to contribute to all development areas. Pre-school education teacher, in addition to being a classroom teacher, s/he is the natural leader and guidance counselor of the class. During this period, a pre-school teacher with an understanding of guidance tries to create a free, comfortable, warm and safe atmosphere for the child to develop in every aspect healthily, to adapt to the school environment and to realize their potential. Since teachers have the most and intense relationship with their students, they are the ones who carefully observe their needs, problems and, developmental characteristics in the school environment. In addition, since teachers are in contact with the parents, they gain the most knowledge about the processes in both school and home life and can influence parents to inform and guide their children's development. Most of the training activities take place in the classroom. Teachers need classroom management skills and guidance competencies when interfering with the undesired behavior. The teachers' being equipped is effective in eliminating or not repeating the negative behaviors of the students. A preschool teacher with strong classroom management and guidance skills will have a substantial impact on children's righteous behavior and increase their academic achievement. Improving the quality of pre-school education and meeting the developmental needs of children require pre-school teachers to become equipped. Supportive studies in the field of classroom management and guidance will contribute to our teachers in this respect. This study aims to investigate the relationship between pre-school teachers' guidance competencies and classroom management skills.

\section{Method}

The research was designed with a relational screening model. The research was conducted in the 2018 academic year with a total number of 170 pre-school teachers, 159 women, and 11 men, working in Istanbul. The first measurement tool used in the research was the "Pre-school Teacher Guidance Competence Scale." The scale was developed by Bilgin (2017). As a result of the factor analysis of the scale, there were 59 items that explained 55,989\% of the total variance and gathered under four factors. Factor load of the scale was found between .746 to .453. The Cronbach's alpha internal consistency coefficients of the Pre-school Teacher Guidance Competence Scale were found .977 for the whole scale; .954 for the sub-dimension, Factor 1: "Supporting Educational Development and Interpersonal Relations"; .943 for the sub-dimension, Factor 2: "Supporting Individual Development and Orientation"; .904 for the sub-dimension, Factor 3: "Supporting Self-acceptance, Individuality and Social Development"; and .909 for the sub-dimension, Factor 4: "Recognizing the Individual, Identifying the Problems and Supporting the Parents". The testretest reliability coefficient of the scale was .71. The second measurement tool used in the research was "Classroom Management Scale for Pre-school Teachers." The scale was developed by Uyanık, Balat, Bilgin, and Sezer (2011). The classroom management scale for pre-school teachers consists of five factors and 35 
items and the total variance explained was $48.3 \%$. When the relationships between the sub-dimensions of the scale were examined, values were found between .20 and .56 and correlation values between the subdimensions of the scale and the total score were found to be between .43 and .87. The Cronbach's alpha values of the whole scale and the sub-dimensions are as follows; for time management and the democratic environment factor; .90, for the sufficiency factor in planning activities; 82, for the arrangement of the physical environment; .79, for the teacher's personal sufficiency factor; .72, and for the problem behavior management factor it was found to be .95. Pearson Product-Moment Correlation Coefficient and Simple Linear Regression were used in the analysis of the research data.

\section{Results}

It was detected that $93.53 \%$ of the teachers participating in the research were female, $6.47 \%$ were male, $51.7 \%$ of them were between $21-30$ years old, $68.2 \%$ were pre-school graduates, $52.4 \%$ of them had professional experience between 6-15 years and $76.5 \%$ of the participants stated that the socio-cultural level of the institution they work for was intermediate level.

According to the results, there is a meaningful relationship between pre-school teachers' guidance competencies and classroom management skills. There is also a significant relationship in terms of the subdimensions of both scales. In the study, it was determined that teachers achieve high scores in terms of guidance competencies, and their level of classroom management skills is high.

As a result of the simple linear regression analysis, it was seen that the guidance competence of pre-school teachers explained about $38 \%$ of the change in classroom management skills of pre-school teachers. At the same time, it was determined that the guidance competence of pre-school teachers was a significant predictor of classroom management skills. It was determined that classroom management skills would improve if the pre-school teachers' guidance competencies were improved.

\section{Conclusion and Discussion}

This research finding, which reveals that pre-school teachers' levels of guidance competence are high, supports Kılıçoğlu's (2013) study. Similarly, the results of Atıc1's (2001) study showed that teachers with a high level of guidance competence could prevent behavioral problems and create an atmosphere in which students can concentrate on academic studies. However, some studies also show that teachers do not consider themselves sufficient in this area (Aliyev et al., 2012; Büyükgöncü, 2013; Bakırcıŏlu, 2003; Tekin, 2012; Yeşilyaprak, 2010). Another finding is that classroom management skill levels of pre-school teachers were found to be high in this study. Researches supporting this result are included in the body of literature (Erdoğan et al., 2010; Egert et al., 2018; Sadık and Dikici Sığırtmaç, 2016; Şentürk and Oral, 2008). Focusing on in-service training activities for pre-school teachers to develop their skills in classroom management and guidance services will be beneficial in increasing the quality of pre-school education. 


\section{GİRIŞ}

Okul öncesi dönem, çocuğun sağlıklı gelişiminin desteklenmesinde, olumlu davranışların kazandırılması ve kalıcılığının sağlanmasında, okul yaşamına karşı olumlu tutumların geliştirilmesinde ve ilkokula hazırlıkta tartışılmaz öneme sahiptir. Çok kıymetli olan bu gelişimsel dönemde görev yapan okul öncesi öğretmenleri sınıf yönetimi ve rehberlik yeterlilikleri açısından daha fazla donanıma sahip olmalıdırlar.

Alan yazında sınıf yönetimi kavramı; öğrencinin gelişiminin takip edilmesi, ortaya çıkabilecek sorunların giderilmesi (Terzi, 2002), öğrenme ortamının düzenlenmesi, sınıf kurallarının oluşturulması ve tüm kaynakların yönetilmesinde (Başar, 2002) ve bireysel farklılıkların (Celep, 2008) göz önünde bulundurularak, fiziksel koşulların ve öğretmen-öğrenci etkileşimi bir bütün olarak (Erden, 1998) değerlendirilmektedir. Aynı zamanda sınıf yönetimi süreçlerinde; öğrencilerin aileleri ile iletişim kurma, öğrencilerin öğrenme ihtiyaçlarına ve ilgilerine göre programı düzenleme gibi çok çeşitli stratejilerin yaygın biçimde kullanıldığı görülmektedir (Reupert ve Woodcock, 2010).

Öğretmenin sınıf ortamında uygulamalarını en ideal şekilde gerçekleştirebilmesi için kullanabileceği en önemli araçlardan biri sınıf yönetimi olarak kabul edilmektedir (Balat, 2011). Manning ve Bucher (2013) sınıf yönetimini; sınıfta, fiziksel ve psikolojik güvenliği sağlayan stratejiler, öğrencilerin davranışlarını düzenleyen ve öz disiplini oluşturmayı sağlayan teknikler, sınıftaki olayların düzenli ilerlemesini sağlayan yöntemlerin tümü olarak tanımlamaktadır. Dolayısı ile etkili bir sınıf yönetiminin temelinde öğretmenin becerileri bulunmakta ve öğretmenin çocuğun ilgi ve ihtiyaçlarını bilmesi, etkili bir sınıf yönetimi için ön koşul olarak kabul edilmektedir (Yalçınkaya ve Tonbul, 2002). Etkili sınıf yönetimi stratejilerine sahip olmak, her öğretmende bulunması gereken önemli bir beceridir (Landau, 2001). Öğretmenin öğretmenlik mesleğine ilişkin sınıftaki temel rolleri; öğrenmeyi sağlamak, öğrencilere rehberlik etmek ve istenmeyen davranışların oluşmasını önlemektir (Denizel Güven, 2005; Kazu, 2007). Bu nedenle başarılı bir sınıf yönetimi için öğretmen liderlik ve rehberlik niteliklerine sahip olmalıdır (Terzi, 2002).

İşmen Gazioğlu ve Mertol İlgar (2010) okul öncesi eğitim döneminde çocukların her yönüyle sağlıklı gelişmeleri, okul ortamına uyum sağlamaları ve kapasitelerini ortaya koyabilmeleri için eğitim çalışmalarının rehberlik hizmetleriyle birlikte yürütülmesi gerektiğini vurgulamaktadır. Eğitim bir süreçtir ve gelişimin de sürekli olduğu gerçeği rehberlik hizmetlerinin eğitimin her kademesinde "gelişimi kolaylaştırma ve gelişim görevlerinin başarılmasında yardımcı olma” işlevini üstlenmesini zorunlu hale getirmiştir. Bu doğrultuda benimsenen gelişimsel rehberlik, bireyin sürekli gelişim halinde olduğu, içinde bulunulan yaş ve gelişim dönemlerinin bir gereği olarak yerine getirmesi 
beklenen bazı gelişimsel görevlerinin olduğu ve bir gelişim basamağını başarı ile geçirenlerin daha sonraki gelişim basamağının gelişim görevlerini daha iyi başaracağı gerçeğine dayanmaktadır. Bu yaklaşımda, çocukların gelişimsel görevlerini başarı ile yerine getirmelerini kolaylaştırmak ve desteklemek için sistemli ve programlı bir şekilde rehberlik hizmetlerinin verilmesi amaçlanmaktadır (Akgün, 2010; Gökçakan, 2008; Yeşilyaprak, 2010).

Gelişimsel rehberlik modeli ile birlikte, öğretmenlere rehberlik hizmetlerinde verilen görevler daha da önem kazanmıştır. Gelişimsel rehberlik modelinin okul öncesi eğitimden lise son sınıfa kadar tüm öğrencilere ulaşmayı hedeflemesi; tedavi değil eğitim odaklı olması öğretmenlerin önemini daha da artırmıştır (Nazlı, 2008). Okul rehberlik hizmetleri ekip çalışmasını gerektirir. Bu ekibin içinde öğretmenlere önemli rollerin düştüğü pek çok uzman tarafindan benimsenmektedir (Harrison, 1993; Myrick, 1997; Erkan, 1999; Doğan, 2000; Yeşilyaprak, 2010). Okullarda öğretmenler, öğrencilerle en fazla ilişki halinde olan bireylerdir. Öğrencilerle daha yoğun ve uzun süreli bir ilişki içinde olduklarından, onları daha iyi tanımakta, sorunları daha erken fark edebilmekte, aileleriyle daha doğrudan bir ilişki kurabilmekte ve risk faktörlerini daha kolay tanımlayabilmektedirler. $\mathrm{Bu}$ durum, öğretmenlerin önleyicilikteki önemli rolünün en açık göstergesidir (Demir, 2010).

Öğretmen; eğitim faaliyetlerini yürütürken sahip sınıf yönetimi becerilerine, çocukların gelişimsel görevlerini takip etmede ve doğru davranışları kazanmalarında (istenmedik davranışları değiştirmede) kendi rehberlik yeterliliklerine başvuracaktır. Öğretmen bu iki alandaki (sınıf yönetimi ve rehberlik yeterlilikleri) beceri ve çabasını arttırdığı oranda öğrencilerinin gelişimsel ve akademik başarıları da olumlu etkilenecektir. Okul öncesi öğretmeninin rehberlik yeterlilikleri alanında geliştirilmesi onun sınıf yönetimi süreçlerinde de daha etkin olmasına katkı sağlayacağından sonuçta öğrencilerin eğitsel ve kişisel gelişimlerine pozitif yönde etki edecektir.

Okul öncesi eğitimde kalitenin artması ve çocukların gelişimsel ihtiyaçlarının karşılanabilmesi okul öncesi öğretmenlerinin daha donanımlı hale gelmesini gerektirmektedir. Öğretmenlerimizin sınıf yönetimi becerilerinde daha da başarılı sonuçlar elde etmelerini sağlamak için onları rehberlik yeterlilikleri açısından da zenginleştirmemiz gerekmektedir. Rehberlik becerileri gelişen öğretmenler öğrencilerinin sadece eğitim çalışmalarıyla sınırlı kalmayıp onlara önleyici ve çözüm üretici rehberlik faaliyetlerini de sunabilen başarılı eğitimciler olacaklardır. Öğretmenlerin daha donanımlı hale gelmesi, öğrencilerin gelişimine ve okul öncesi eğitimin kalitesine olumlu katkı sağlayacak olması, bu araştırmanın önemini oluşturmaktadır.

Okul öncesi dönemde rehberlik hizmetleri ile ilgili olarak literatürde yer alan araştırmaların son derece kısıtlı sayıda olması dikkate alındığında araştırmanın; okul öncesi öğretmenlerinin rehberlik 
yeterliliklerinin geliştirilmesinin onların sınıf yönetimi becerilerine olumlu yönde katkı sağlaması bulgusu bu konu alanındaki çalışmaların arttırılmasına, dolayısıyla öğrenciye/veliye, öğretmene ve alana önemli katkı sağlayacaktır.

Araştırmanın temel amacı okul öncesi eğitim kurumlarında görev yapan öğretmenlerin rehberlik yeterlilikleri ile sınıf yönetimi becerileri arasındaki ilişkinin incelenmesi olarak belirlenmiştir.

\section{YÖNTEM}

\section{Araştırmanın Evreni ve Örneklemi}

İki ve daha çok sayıdaki değişken arasında birlikte değişim varllğını ve/veya derecesini belirleyebilmeyi amaçlayan araştırma modeline "ilişkisel tarama modeli" adı verilmektedir (Karasar, 1999). Araştırmada ilişkisel tarama modeli kullanılmışır. Çalışma grubu 2018 eğitim ve öğretim yllinda İstanbul ili Anadolu ve Avrupa yakasında yer alan ve basit rastgele örnekleme yöntemiyle seçilen 159’u kadın ve 11’i erkek olan okul öncesi eğitim kurumlarında görev yapmakta olan toplam 170 okul öncesi öğretmeni oluşturmaktadır.

\section{Veri Toplama Araçları}

Bilgi Formu: araştırmacı tarafından hazırlanan bilgi formunda öğretmenlerin; cinsiyet, yaş, öğrenim durumu, çalışma y1lı ve okulun sosyo-kültürel düzeyi gibi bazı psikometrik özelliklerine ilişkin sorular yer almaktadir.

Okul Öncesi Öğretmeni Rehbetlik Yeterlilikleti Ölçeği: Okul öncesi öğretmenlerine yönelik rehberlik yeterlilikleri ölçeği Bilgin (2017) tarafindan geliştirilmiştir. Ölçeğin faktör analizi sonucunda toplam varyansin \% 55,989’unu aç1klayan ve dört faktör altında toplanan 59 madde vardır. Ölçeğin faktör yükleri; .746 ile .453 arasında sıralanmaktadır. Okul Öncesi Öğretmeni Rehberlik Yeterlilikleri Ölçeği’nin Cronbach Alfa iç tutarlılık katsayıları ölçeğin bütünü için .977, Faktör1:.954, Faktör 2:.943, Faktör 3: .904, Faktör 4: .909 bulunmuştur. Ölçeğin toplamı için test tekrar test güvenirlik katsayısı .71 olarak hesaplanmıştır.

Sinıf Yönetimi Ölçeği: Okul öncesi öğretmenlerine yönelik sınıf yönetimi ölçeği Uyanık Balat, Bilgin ve Sezer (2011) tarafindan geliştirilmiştir. Okul öncesi öğretmenlerine yönelik sınıf yönetimi ölçeği beş faktörlü ve 35 maddeden oluşmakta ve açıklanan toplam varyans \%48.3’tür. Ölçeğin alt boyutlarının birbirleriyle olan ilişkileri incelendiğinde .20 ile .56 arasında değişen değerler aldığı ve ölçeğin alt boyutları ile toplam puan arasında .43 ile .87 arasında değişen korelasyon değerleri 
bulunmuştur. Ölçeğin alt boyutlarının Cronbach Alfa değerleri faktör1: .90, faktör 2:. 82, faktör 3: .79, faktör 4: .72 ve faktör 5: için .95 olarak hesaplanmıştır. Ölçeğin toplam cronbach alfa katsayısı ise, .91 olarak ve test tekrar test güvenirlik katsayısı . 95 olarak hesaplanmıştır.

Araștırmacının, ideal gördüğü ve normal olarak yapmak isteyip de çeșitli nedenlerle vazgeçmek zorunda kaldığı şeyler araştırmanın sınırlılıklarıdır. Bu ideal koşullar, bazen araştırmacının kontrolü ve etki alanı dışında olduğu, bazen de fayda maliyet açısından pratik olmadığı için gerçekleştirilemeyebilir (Karasar, 1999). Buna istinaden araştırmada kullanılan ölçeklerin toplam puanları üzerinden işlem yapılmış olması araştırmanın sınırlılığını oluşturmaktadır.

\section{BULGULAR}

Aşağıda araştırmaya katılan öğretmenlerin psikometrik özelliklerine yönelik bulgulara yer verilmiştir.

Tablo 1. Araştırmaya Katılan Öğretmenlerin Psikometrik Özellikleri

\begin{tabular}{|c|c|c|}
\hline Cinsiyet & $\mathbf{N}$ & $\%$ \\
\hline Kadın & 159 & 93,53 \\
\hline Erkek & 11 & 6,47 \\
\hline Toplam & 170 & 100,0 \\
\hline Yaş & $\mathbf{N}$ & $\%$ \\
\hline 20 yaş ve altı & 1 & 0,6 \\
\hline $21-25$ yaş & 41 & 24,1 \\
\hline $26-30$ yaş & 47 & 27,6 \\
\hline $31-35$ yaş ve üstü & 80 & 47,1 \\
\hline Eksik Data & 1 & 0,6 \\
\hline Toplam & 170 & 100,0 \\
\hline Eğitim Durumu & $\mathbf{N}$ & $\%$ \\
\hline Meslek Lisesi Çocuk Gelişimi & 5 & 2,9 \\
\hline Çocuk Gelişimi Önlisans & 20 & 11,8 \\
\hline Okul Öncesi Öğretmenliği(açık öğretim) & 6 & 3,5 \\
\hline Okul Öncesi Öğretmenliği & 116 & 68,2 \\
\hline Lisans Üstü & 10 & 5,9 \\
\hline Halen öğrenci & 5 & 2,9 \\
\hline Diğger & 8 & 4,7 \\
\hline Toplam & 170 & 100,0 \\
\hline Mesleki Deneyim & $\mathbf{N}$ & $\%$ \\
\hline $1-5 \mathrm{y} 1 \mathrm{l}$ & 61 & 35,9 \\
\hline $6-10$ y1l & 44 & 25,9 \\
\hline $11-15 \mathrm{y} 1 \mathrm{l}$ & 45 & 26,5 \\
\hline \multirow[t]{2}{*}{$16-20 \mathrm{y} 1 \mathrm{l}$} & 8 & 4,7 \\
\hline & 2019 & $\begin{array}{l}\text { Journal of Early Childhood Studies } \\
\text { Volume } 3 \cdot \text { Issue } 2 \cdot \text { October }\end{array}$ \\
\hline
\end{tabular}




\begin{tabular}{lcc}
21 yll ve fazlas1 & 12 & 7,1 \\
Toplam & 170 & 100,0 \\
\hline Sosyo Kültürel Düzey & $\mathrm{N}$ & $\%$ \\
\hline Alt düzey & 6 & 3,5 \\
Orta düzey & 130 & 76,5 \\
Üst düzey & 34 & 20,0 \\
Toplam & 170 & 100,0 \\
\hline
\end{tabular}

Tablo 1 incelendiğinde araştırmaya katılan öğretmenlerin \%93,53’ünün kadın, \%6,47’sinin erkek, \%51,7’sinin 21-30 yaş aralığında olduğu, \%68,2'sinin Okul Öncesi Öğretmenliği mezunu olduğu, \%52,4'ünün 6-15 yıl arasında mesleki deneyime sahip olduğu ve \%76,5’inin çalıştıkları kurumun sosyo-kültürel düzeyini orta düzey olarak belirttikleri tespit edilmiştir.

Tablo 2. Okul Öncesi Öğretmenlerinin Rehberlik Yeterlilik Düzeyleri

\begin{tabular}{lccc}
\hline \multicolumn{1}{c}{ Rehberlik Yeterlilik Boyutları } & N & $\overline{\boldsymbol{X}}$ & Ss \\
\hline Eğitsel gelişimin desteklenmesi, sağllklı iletişim ve kişilerarası ilişkiler & 170 & 81.130 & 7.747 \\
Bireysel gelişimin desteklenmesi ve oryantasyon & 170 & 72.073 & 6.788 \\
Kendini kabul, benlik ve sosyal gelişimin desteklenmesi & 170 & 56.535 & 5.749 \\
Bireyi tanıma, sorunları tespit ve ebeveynin desteklenmesi & 170 & 53.835 & 5.183 \\
Rehberlik yeterlilikleri genel & 170 & 263.573 & 24.084 \\
\hline
\end{tabular}

Tablo 2'de araştırmaya katılan okul öncesi öğretmenlerinin rehberlik yeterlilikleri açısından Eğitsel Gelişimin Desteklenmesi, Sağlıklı İletişim Ve Kişilerarası ilişkiler boyutunda 81.130, Bireysel Gelişimin Desteklenmesi Ve Oryantasyon boyutunda 72.073 ile yüksek puan aldıkları görülmektedir. Eğitsel gelişimin desteklenmesi, sağlıklı iletişim ve kişilerarası ilişkiler alt boyutunda 18 madde mevcut olup minimum 18, maksimum 90 puan alınabilir. Bireysel gelişimin desteklenmesi ve oryantasyon alt boyutunda 16 madde mevcut olup minimum 16, maksimum 80 puan alınabilir. Kendini kabul, benlik ve sosyal gelişimin desteklenmesi alt boyutunda 13 madde mevcut olup minimum 13, maksimum 65 puan alınabilir. Bireyi tanıma, sorunları tespit ve ebeveynin desteklenmesi alt boyutunda 12 madde mevcut olup minimum 12, maksimum 60 puan alınabilir.

Tablo 3. Okul Öncesi Öğretmenlerinin Sınıf Yönetimi Beceri Düzeyleri

\begin{tabular}{lccc}
\hline \multicolumn{1}{c}{ Sinıf Yönetimi } & N & $\overline{\boldsymbol{X}}$ & Ss \\
\hline Zaman yönetimi ve demokratik ortam & 170 & 71.181 & 6.662 \\
Etkinlikleri planlamada yeterlik & 170 & 32.990 & 4.153 \\
Fiziksel çevrenin düzenlenmesi & 170 & 16.432 & 2.866 \\
Öğretmenin kişisel yeterliliği & 170 & 12.182 & 1.851 \\
Sorun davranışların yönetimi & 170 & 13.679 & 1.778 \\
Sınıf yönetimi düzeyi genel & 170 & 146.464 & 13.805 \\
\hline
\end{tabular}


Tablo 3’te araştırmaya katılan okul öncesi öğretmenlerinin sınıf yönetimi becerileri açısından yüksek puanlar aldıkları görülmektedir. Zaman yönetimi ve demokratik ortam alt boyutunda 16 madde mevcut olup minimum 16, maksimum 80 puan alınabilir. Etkinlikleri planlamada yeterlik alt boyutunda 8 madde mevcut olup minimum 8 , maksimum 40 puan alınabilir. Fiziksel çevrenin düzenlenmesi alt boyutunda 4 madde mevcut olup minimum 4, maksimum 20 puan alınabilir. Öğretmenin kişisel yeterliliği alt boyutunda 3 madde mevcut olup minimum 3, maksimum 15 puan alınabilir. Sorun davranışların yönetimi alt boyutunda 4 madde mevcut olup minimum 4, maksimum 20 puan alınabilir.

Tablo 4. Okul Öncesi Öğretmenlerinin Rehberlik Yeterlilikleri ve Sınıf Yönetimi Becerileri Arasındaki İlişki

\begin{tabular}{|c|c|c|c|c|c|c|c|}
\hline \multirow[b]{2}{*}{$\begin{array}{l}\text { Rehberlik } \\
\text { Yeterlilik } \\
\text { Boyutları }\end{array}$} & & \multicolumn{6}{|c|}{ Sınıf Yönetimi Boyutları } \\
\hline & & $\begin{array}{c}\text { Zaman } \\
\text { yönetimi } \\
\text { ve } \\
\text { demokratik } \\
\text { ortam } \\
\end{array}$ & $\begin{array}{c}\text { Etkinlikleri } \\
\text { planlamada } \\
\text { yeterlik }\end{array}$ & $\begin{array}{c}\text { Fiziksel } \\
\text { çevrenin } \\
\text { düzenlenmesi }\end{array}$ & $\begin{array}{l}\text { Öğretmenin } \\
\text { kişisel } \\
\text { yeterliliği }\end{array}$ & $\begin{array}{c}\text { Sorun } \\
\text { davranışların } \\
\text { yönetimi }\end{array}$ & $\begin{array}{l}\text { Sinif } \\
\text { yönetimi } \\
\text { genel }\end{array}$ \\
\hline $\begin{array}{l}\text { Eğitsel gelişimin } \\
\text { desteklenmesi, } \\
\text { sağlıklı iletişim ve } \\
\text { kişilerarası ilişkiler }\end{array}$ & $\mathrm{r}$ & $.647^{* *}$ & $.530^{* *}$ & $.316^{* *}$ & $.402^{* *}$ & $.297^{* *}$ & $.576^{* *}$ \\
\hline $\begin{array}{l}\text { Bireysel gelişimin } \\
\text { desteklenmesi ve } \\
\text { oryantasyon }\end{array}$ & $\mathrm{r}$ & $.639^{* *}$ & $.514^{* *}$ & $.338^{* *}$ & $.431^{* *}$ & $.245^{*}$ & $.576^{* *}$ \\
\hline $\begin{array}{l}\text { Kendini kabul, } \\
\text { benlik ve sosyal } \\
\text { gelişimin } \\
\text { desteklenmesi }\end{array}$ & $\mathrm{r}$ & $.559^{* *}$ & $.610^{* *}$ & $.306^{* *}$ & $.503^{* *}$ & .149 & $.573^{* *}$ \\
\hline $\begin{array}{l}\text { Bireyi tanıma, } \\
\text { sorunları tespit ve } \\
\text { ebeveynin } \\
\text { desteklenmesi }\end{array}$ & $\mathrm{r}$ & $.644^{* *}$ & $.556^{* *}$ & $.343^{* *}$ & $.437^{* *}$ & $.265^{* *}$ & $.596^{* *}$ \\
\hline $\begin{array}{l}\text { Rehberlik } \\
\text { yeterlilikleri genel }\end{array}$ & $\mathrm{r}$ & $.660^{* *}$ & $.587^{* *}$ & $.345^{* *}$ & $.471^{* *}$ & $.252^{*}$ & $.615^{* *}$ \\
\hline
\end{tabular}

Tablo 4'de araştırmaya katılan okul öncesi öğretmenlerinin rehberlik yeterlilikleri ve sınıf yönetimi düzeyleri arasındaki ilişki incelendiğinde; her iki ölçeğin alt boyutları arasında ve ölçeklerin genel puanları arasında anlamlı bir ilişki olduğu tespit edilmiştir.

Tablo 5. Rehberlik Yeterlikleri ve Sınıf Yönetimi Beceri Düzeyleri Değişkenlerine Ait Basit Doğrusal Regresyon Analizi Sonuçları

\begin{tabular}{|c|c|c|c|c|c|c|c|c|}
\hline & Değişken & B & $\begin{array}{c}\text { Standart } \\
\text { Hata }\end{array}$ & $\beta$ & $\mathbf{t}$ & $\mathrm{p}$ & $\underset{\mathbf{r}}{\text { İkili }}$ & $\underset{r}{\text { Kismi }}$ \\
\hline \multirow[b]{2}{*}{ Sınıf Yönetimi } & Sabit & 1.352 & .266 & & 5.081 & .000 & & \\
\hline & $\begin{array}{l}\text { Rehberlik } \\
\text { yeterlilikleri }\end{array}$ & .601 & .059 & .615 & 10.118 & $.000^{*}$ & .615 & .615 \\
\hline $\begin{array}{l}\mathrm{R}=, 615 \\
\mathrm{R}^{2}=, 379\end{array}$ & & & & & & & & \\
\hline
\end{tabular}


Düzeltilmiş $\mathrm{R}^{2}=, 375$

$\mathrm{n}=170$

$\mathrm{F}=102,36$

$\mathrm{p}=, 000^{*}$

$* \mathrm{p}<, 001$

Tablo 5’te görüldüğü gibi okul öncesi öğretmenlerinin rehberlik yeterlikleri ve sinıf yönetimi beceri düzeylerine ait varyans analizi sonucu $(\mathrm{F}=, 102,36 ; \mathrm{p}<, 001)$ rehberlik yeterlikleri ile kurulan regresyon modelinin istatistiksel olarak anlamlı olduğunu göstermektedir. Tablo 5'te regresyon katsayılarının anlamlılığına ilişkin t-testi sonuçları incelendiğinde okul öncesi öğretmenlerinin rehberlik yeterliliklerinin sınıf yönetimi becerileri üzerinde anlamlı bir yordayıcı olduğu görülmektedir. Okul öncesi öğretmenlerinin rehberlik yeterlikleri ile sınıf yönetimi becerileri arasında ilişki pozitif ve orta düzeyli iken $(r=, 615)$, diğer değişkenler kontrol edildiğinde bu iki değişken arasındaki ilişkinin yine aynı düzeyde ( $\mathrm{r}=$,615) kaldığı görülmektedir. Regresyon analizi sonuçlarına göre sınıf yönetiminin yordanmasına ilişkin regresyon eşitliği şu şekilde oluşmuştur: simıf yönetimi düreyleri $=1.352+.601$ rebberlik yeterlilikleri

\section{SONUÇ ve TARTIŞMA}

Okul öncesi öğretmenlerinin rehberlik yeterlilikleri ile sınıf yönetimi becerileri arasındaki ilişkinin incelendiği bu araştırmada, öğretmenlerin rehberlik yeterlilikleri açısından yüksek puanlar aldıkları bulunmuştur. Arslan Kılıçoğlu’nun (2013) araştırmasının sonuçlarında; okulöncesi öğretmenleri, kişisel rehberlik uygulamalarında kendilerini büyük ölçüde yeterli bulmaktadırlar. Okulöncesi öğretmenleri, eğitsel rehberlik faaliyetlerini eğitim sürecinde genel anlamda uyguladıklarını düşünmekte ve kendilerini bu konuda büyük ölçüde yeterli hissetmektedirler. Okul öncesi öğretmenleri mesleki rehberlik faaliyetlerini eğitim sürecinde kısmen uygulamakta ve kendilerini bu konuda bir ölçüde yetersiz alg1lamaktadırlar. Okul türü değişkeni yani öğretmenlerin bağımsız anaokulu ya da ilköğretime bağlı anasınıflarında görev yapıyor olmaları kişisel, eğitsel ve mesleki rehberlik açısından yeterlilik algılarını etkilememektedir. Öğretmenlerin mesleki deneyiminin az ya da çok olması kişisel, eğitsel ve mesleki rehberlikle ilgili yeterlilik algılarını etkilememektedir. Lisans eğitimi sürecinde okul öncesi eğitimde rehberlikle ilgili aldığı dersleri yeterli bulan ve bulmayan okulöncesi öğretmenlerinin olması kişisel, eğitsel ve mesleki rehberlikle ilgili yeterlilik algıları benzerlik göstermektedir. Atıcı'nın (2001) yapmış olduğu araştırmanın sonuçlanı yüksek rehberlik yetkinlik düzeyindeki öğretmenlerin davranış problemlerini önleyebildiklerini ve öğrencilerin akademik çalışmalara konsantre olabildiği bir atmosfer yaratabildiklerini ortaya koymuştur. Benzer şekilde bu araştırmanın bulgularında da öğretmenlerin özellikle "Sağlıklı İletişim ve Kişilerarası 
ilişkiler" ile "Bireysel Gelişimin Desteklenmesi ve Oryantasyon" alt boyutlanında rehberlik yeterliliklerinin yüksek düzeyde olduğu belirlenmiştir.

Okul öncesi eğitim alanında çalışan öğretmenlerin rehberlik yeterlilikleri konusu oldukça yeni bir çalışma alanı olduğundan gerek yurt içi gerekse yurt dışı kaynaklarda bu konu alanına ilişkin yapılmış araştırmalara ulaşılamamıştır. Ancak okul öncesi eğitimde rehberlik hizmetlerinin önemine ilişkin çalışmalar öğretmenlerin rehberlik yeterliliklerinin geliştirilmesinin alan açısından önemini ön plana çıkarmaktadır. Tekin'in (2012) çalışmasındaki okul öncesi öğretmenleri, çocuğa ve aileye yapılacak rehberlik hizmetleri ve çocuk psikolojisi hakkında yeterince bilgiye sahip olmadıklarını belirtmiş olup bu konuda hizmet içi eğitime gereksinim duyduklarını vurgulamışlardır. Öte yandan, Aliyev vd. (2012) yaptıkları çalışmada, okul öncesi eğitim kurumlarında görev yapan idareciler ve psikolojik danışmanların da okul öncesi eğitimde psikolojik danışma ve rehberlik hizmetlerini sunmak konusunda yeterli bilgi ve donanıma sahip olmadıklarını, lisans eğitimleri süresince bu konuda sınırlı sayıda ders aldıklarını belirlemişlerdir. Bir başka araştırmada da Arslan Kılıçoğlu (2013), okul öncesi öğretmenlerinin etkili rehberlik uygulamalarının gerçekleştirilmesinde eğitim ihtiyaçlarının belirlenmesi üzerinde durmuş, okul öncesi eğitim öğretmenlerinin birtakım sorunların çözümünde yetersiz kaldıklarını, her okulda rehber öğretmen bulunmamasından dolayı da bu sorunların çözülemediğini ortaya koymuştur. Kardeş ve Akman (2016) çalışmalarında rehber öğretmenlerin yaptığ1 çalışmalar ile öğretmenlerin beklediği çalışmaların çoğu zaman örtüşmediğini ve öğretmenlerin bu çalışmaları gereksiz bulduklarını, verilen rehberlik hizmetinin verimsiz olduğunu, okul öncesi öğretmenlerinin rehberlik konusundaki bilgilerinin arttırılmasının öğretmenlerin rehberlik alanından beklentilerinin yükselmesine sebep olacağını bunun da rehberlik servislerinin daha işlevsel bir şekilde çalışmasına katkıda bulunacağını vurgulamaktadırlar. Bu çalışmaları destekler nitelikte bir başka araştırmayı gerçekleştiren Büyükgöncü ( 2013) araştırmasında, okul öncesi öğretmenlerinin bireyi tanıma teknikleri konusunda ortak bir anlayışa sahip olmadıklarını. Ayrıca, okul öncesi öğretmenlerinin çoğu, bireyi tanıma teknikleri konusunda hizmet içi eğitime ihtiyaç duymakta, yarıya yakını ise bu teknikleri kullanma konusunda yeterli bilgiye sahip bulunmadığını tespit etmiştir. Bakırcığlu (2003) okul öncesi öğretmenlerinin eğitsel rehberlikle ilgili yeterlilik algıları arasında anlamlı farklılık bulunmadığını bulmuştur. Yeşilyaprak (2010) ise okul öncesi öğretmenlerinin mesleki rehberlik açısından kendilerini yeterli alg1lamadıklanını ifade etmektedir.

Bu araştırmada okul öncesi öğretmenlerinin sınıf yönetimi beceri düzeyleri de yüksek bulunmuştur. Bu bulguyu destekler nitelikte Sadık ve Dikici Sığırtmaç'ın (2016) araştırmasındaki sonuçlar da okul öncesi öğretmenlerinin sınıf yönetimi becerilerinin yüksek düzeyde olduğunu göstermektedir. 
Literatürde yer alan diğer araştırmalar bunun tersi yönünde bilgi içermektedir. Şentürk ve Oral'ın (2008) “Türkiye'de Sınıf Yönetimi ile İlgili Yapılan Bazı Araştırmaların Değerlendirilmesi” adlı çalışması, öğretmenlerin sınıf yönetiminin birçok boyutunda yetersiz olduklarını göstermektedir. Erdoğan vd. (2010) yöneticilerin, öğretmenlerin ve ailelerin sınıf yönetimi ve disiplin problemleri ile ilişkili görüşlerinin incelendiği çalsşma sonucunda öğretmenlerin niteliklerinin iyileştirilmesi önerisi dikkat çekici bir ifade olarak karşımıza çıkmaktadır. Egert vd. (2018) araştırmasında; öğretmenleri eğitim programlarıyla desteklemenin sınıf kalitesini ve öğrenci öğrenimini iyileştirdiğini ifade etmektedirler. Toran (2019) araştırmasında, öğretmenin yetkinlik hissi inanç düzeyinin, okul öncesi öğretmenlerinin sınıf yönetimi becerilerinin bir yordayıcısı olduğunu tespit etmiş ve okul öncesi öğretmeninin mesleki yeterliliğinin okul öncesi eğitimin kalitesini arttırmada oldukça belirleyici bir rol oynadığını belirtmiştir.

Araştırma kapsamında okul öncesi öğretmenlerinin rehberlik yeterlilikleri ve sınıf yönetimi düzeyleri arasındaki ilişkiye bakılmış ve her iki arasında anlamlı bir ilişki olduğu tespit edilmiştir. $\mathrm{Bu}$ bulgu nedeniyle okul öncesi öğretmenlerinin rehberlik yeterliklerinin sınıf yönetimi becerileri düzeylerinin anlamlı bir yordayıcısı olup olmadığına bakıldığında ise rehberlik yeterliliklerinin sınıf yönetimi becerileri üzerinde anlamlı bir yordayıcı olduğu bulunmuştur. Bu sonuca istinaden okul öncesi öğretmenlerinin rehberlik yeterlilikleri geliştirildiği takdirde sınıf yönetimi becerilerinin de gelişeceği tespit edilmiştir. Ho vd. (2016) erken çocukluk eğitiminde okul düzeyinde öğretmen yeterlilikleri ile okul temelli mesleki öğrenme topluluğu (PLC) uygulamaları arasındaki ilişkiyi araştırdıkları çalışmalarında; öğretmenlerin yeterliliklerinin oranı arttıkça öğrenme uygulamalarına yönelik algılarının da olumlu yönde arttığını ortaya koymaktadır. Öğretmen niteliklerinin yükseltilmesi, ABD, İngiltere, Singapur ve Kore dahil olmak üzere birçok ülkede politika gündeminde bir öncelik olmuştur. Sürekli mesleki gelişim, öğretmenin ve öğrenmenin kalitesini iyileştirmek için öğretmenlerin profesyonel öğrenimini geliştirmek için kilit bir strateji olarak da kullanılmıştır. Shewark vd. (2018) öğretmenlerin sınıf iklimi yönetiminin sonuçları üzerine gerçekleştirdikleri araştırmada; iyi yönetilen, duygusal olarak olumlu okul öncesi sınıfların, akademik ve sosyal başarıyı teşvik ettiğini, erken çocukluk döneminde öğretmenlerin sınıf iklimi ve kendi duygusal refahlarını yönetme konusunda daha iyi bir rehberlikle desteklenmesi gerektiğini ve öğretmen eğitimi programlarına yer verilmesi gerektiğini vurgulamışlardır. Alanyazında bu konu alanında başka araştırma çalışmalarının bulunmadığı görüldüğünden yapılacak yeni çalışmaların alana önemli katkılar sağlayacağı söylenebilir.

Okul öncesi eğitimin kalitesinin arttırılmasına önemli katkı sağlayacağından, okul öncesi öğretmenlerinin sınıf yönetimi ve özellikle rehberlik konularında hizmet içi eğitim çalışmalarıyla 
desteklenmesi önerilebilir. Bu araştırma, öğretmenlerin sınıf yönetimi becerileri ile rehberlik yeterlilikleri arasındaki ilişkinin incelenmesiyle sınırlandırılmıştır. Öğretmen niteliklerinin geliştirilmesinde diğer değişkenlerin de etkisine bakılacak araştırmalara yer verilmesi alana büyük katkılar sağlayacaktır. Bu konu alanı ile ilgili daha fazla nitel ve nicel araştırmalara ihtiyaç bulunmaktadir.

\section{KAYNAKÇA}

Akgün, E. (2010). Okul öncesi ögretmenlerinin bakıs açısılla anasmuflarndaki rehberlik bizmetlerinin değerlendirilmesi. İlk:̈̈rretim Online, 9(2), 474-483.

Aliyev, R., Erguner-Tekinalp, B., Ulker, R., \& Shine-Edizer, F. (2012). The perceptions of school counselors and principals towards new psychological counseling and guidance services in early childhood education in Turkey. Educational Sciences: Theory and Practice, 12(4), 30833098 .

Arslan Kulıçoğlu, E. A. (2013). Okul öncesi eğitimi öğretmenlerinin etkili rehberlik uygulamalarmın gerçekleștirilmesinde eğitim ibtiyaçlarmmn belirlenmesi. (Yayımlanmamış Yüksek Lisans Tezi). Selçuk Üniversitesi Sosyal Bilimler Enstitüsü, Konya.

Atıcı, M. (2001). Yüksek ve düşük yetkinlik düzeyine sahip öğretmenlerin sınıf yönetimi stratejileri. Kuram ve Uygulamada Ë̆itim Yönetimi, 28(28), 483-499.

Bakırcioglu, R. (2003). Rebberlik ve psikolojik damısma. Ankara: Anı Yayıncilik

Balat, G. U. (2011). Sinıf Yönetimi Kavramı ve Sinıf Yönetim Modelleri. G. U. Balat \& H. Bilgin (Ed) Okul Öncesi Ë̆itimde Simf Yönetimi. (ss. 1-14), Ankara: Eğiten Kitap

Başar, H. (2002). Simffyönetimi. Ankara: Pegem.

Bilgin, H. (2017). Development of A Preschool Teacher's Guidance Qualifications Scale and Its Psychometric Properties. Journal of Education and Training Studies. 5(9), 83-93.

Bowman, R. (1983). Effective classroom management: A primer'for practicing professionals, Clearing House, 57(3), p.116-118.

Büyükgöncü, N. (2013). Okul öncesi eğitim kurumlarnda uygulanan bireyi tanıma tekniklerinin ögretmen görüsü açısından değerlendirilmesi. Yayınlanmamış Yüksek Lisans Tezi, Erciyes Üniversitesi, Kayseri.

Celep, C. (2008). Sinffyönetiminde kuram ve uygulama. Ankara: PegemA Yayınc1lik

Demir, İ. (2010). Önleyici rehberlik hizmetleri. E. İ.Gazioğlu \& Ş. M. İlgar (Ed). Öğretmen ve ögretmen adaylar için rebberlik. (s.234-255). Ankara: Pegem Pegem A Yayıncilık

Denizel Güven, E., Cevher, F.N. (2005). Okul öncesi öğretmenlerinin sınıf yönetimi becerilerinin çeşitli değişkenler açısından incelenmesi. Pamukkale Üniversitesi Eğitim Fakültesi Dergisi, 18(18), 71-92.

Doğan, S. (2000). Pratik bir sınıf rehberlik ve psikolojik danışma programı. Kuram ve Uygulamada Egitim Yönetimi Dergisi, 6(1), 125-140.

Egert, F., Fukkink, R. G., \& Eckhardt, A. G. (2018). Impact of in-service professional development programs for early childhood teachers on quality ratings and child outcomes: A metaanalysis. Review of Educational Research, 88(3), 401-433.

Erden, M. (1998). Öğretmenlik mesleğine giriş. İstanbul: Alkım. 
Erdoğan, M., Kurşun, E., Şişman-Tan, G., Saltan, F., Gök, A., ve Yıldız, İ. (2010). A Qualitative study on classroom management and classroom discipline problems, reasons, and solutions: A case of information technologies class, Kuram ve Uygulamada Ë̆itim Bilimleri, 10 (2), p.881-891.

Harrison, T.C. (1993). The school counselor as consultant/coordinator. Managing Your School Counseling Program: K-12 Developmental Strategies. Edi. Joe Wittmer, Minneapolis Educational Media Corporation, p. 131-150.

Ho, D., Lee, M., \& Teng, Y. (2016). Exploring the relationship between school-level teacher qualifications and teachers' perceptions of school-based professional learning community practices. Teaching and Teacher Education, 54, 32-43.

İşmen Gazioğlu, E. ve Mertol İlgar, Ş. (Ed.) (2010). Öğretmen ve ögretmen adaylar için rebberlik. Ankara: Pegem.

Karasar, N., (1999). Bilimsel araștırma yöntemi. Ankara: Nobel.

Kardeş, S., \& Akman, B. (2016). Okul öncesi eğitim kurumu yönetici ve öğretmenlerinin rehber öğretmenlerin rollerine ilişkin algılarının incelenmesi. Pegem Eğitim Ve Öğretim Dergisi, 6(3), 393-412.

Kazu, H. (2007). Öğretmenlerin sınıfta istenmeyen davranışların önlenmesi ve değiştirilmesine yönelik stratejileri uygulama durumları. Milli Ë̆itim Dergisi, 175(5), 7-66.

Manning, M.L., \& Bucher, K.T. (2013). Classroom management: models, applications, and cases, 3rd edition. Upper Saddle River, NJ: Pearson \& Merrill Prentice Hall

Landau, B. M. (2001, april). Teaching classroom management: a stand-alone necessity for preparing new teachers. Annual Meeting of the American Educational Research Association. Seattle, WA.

Myrick, D.R. (1997). Developmental guidance and counseling: a practical approach. Third edition, Minneapolis: Educational Media Corporation.

Nazlı, S. (2008). Öğretmenlerin değişen rehberlik hizmetlerini ve kendi rollerini alg1lamaları. Balkesir Üniversitesi Sosyal Bilimler Enstitüsü Dergisi, 11(20), 11-25.

Reupert, A., \& Woodcock, S. (2010). Success and near misses: Pre-service teachers' use, confidence and success in various classroom management strategies. Teaching and Teacher Education, 26(6), 1261-1268.

Sadık, F., \& Dikici Sığırtmaç, A. (2016). Okul öncesi öğretmenlerinin sınıf yönetim becerileri ve uygulamalarına yönelik görüşlerinin incelenmesi. Turkish Studies, 11(14), 631-664.

Shewark, E.A., Zinsser, K.M., ve Denham, S. A. (2018). Teachers' perspectives on the consequences of managing classroom climate, Child and Youth Care Forum, 47(6), 787-802.

Şentürk, H. ve Oral, B. (2008). Türkiye'de sınıf yönetimi ile ilgili bazı araştırmaların değerlendirilmesi. Elektronik Sosyal Bilimler Dergisi, 7(26), 1-13.

Tekin, G. (2012). Counseling and guidance services in early childhood education: the case of public preschools in Malatya, Turkey. US-China Education Review, 10, 875-880.

Terzi, A. R. (2002). Sınıf yönetimi açısından etkili öğretmen davranışlanı. Milli Eğitim Dergisi, 155, 162-169.

Toran, M. (2019). Does sense of efficacy predict classroom management skills? An analysis of the pre-school teacher's professional competency. Early Child Development and Care, 189(8), 1271-1283. 
Uyanık Balat, G., Bilgin, H. ve Sezer, T. (2011). Okul öncesi öğretmenlerine yönelik sınıf yönetimi ölçeğinin geliştirilmesi ve psikometrik özellikleri. Ulusal Okul Öncesi Eğitim Kongresi içinde (s. 101-109). İstanbul: Marmara Üniversitesi.

Yalçınkaya, M. ve Tonbul, Y. (2002). İlköğretim okulu sınıf öğretmenlerinin sınıf yönetimi becerilerine ilişkin alg1 ve gözlemler. Ege Eğitim Dergisi 2(1), 1-10.

Yeşilyaprak, B. (2010). Eğitimde rehberlik hižmetleri, gelişimsel yaklaşım. Ankara: Nobel Yayınclik 